\title{
Risk Mitigation Via Integrating House of Risk and Probability Impact Matrix in Halal Food Supply Chain
}

\author{
Fitra Lestari a*, Ahmad Mas'ari a, Silfia Meilani a, Irsan Nuari Riandika ${ }^{\text {b }}$, Abu \\ Bakar Abdul Hamid c \\ a Department of Industrial Engineering, UIN Sultan Syarif Kasim, Riau, Indonesia \\ b Master student of Management, Riau University, Indonesia \\ c Putra Business School (PBS), Universiti Putra Malaysia, Malaysia \\ * Corresponding author: fitra.lestari@uin-suska.ac.id
}

\section{ARTICLE INFO}

Article history

Received January 27, 2021

Revised June 14, 2021

Accepted July 10, 2021

Available Online August 31, 2021

Keywords

Halal Food Industry

House of Risk

Risk Mitigation

Supply Chain Operations Reference

Probability Impact Matrix

\begin{abstract}
One of the food industry challenges is how to identify sources of risk by considering the halal concept. This study aimed to identify risks and determine risk handling priorities in the supply chain strategy of halal food. This research offered integration of the house of risk and the probability impact matrix to manage risk mitigation in the halal food industry. A case study in the halal food industry was applied in Indonesia based on Supply Chain Operations Reference (SCOR). This study identified 27 risk events and 31 risk agents through 2 phases. Result research showed that employees who did not have special skills (A20) had the highest risk. Moreover, reward and punishment to employees (PA16) was the best proactive action for making effective improvements. The implication of this research is to provide recommendations to management in mitigating risks in the halal food industry.
\end{abstract}

This is an open-access article under the CC-BY-SA license.

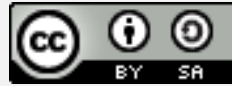

\section{Introduction}

The food industry produces some product variety to fulfill consumer needs. In the national and international markets, there are many food industries to satisfy customer requirements. The food industry has several complex supply chain processes. Several studies declare that the supply chain strategy in the food industry has many problems in its business processes [1] [2]. One of the problems in the food industry supply chain is risk management. There are many risks in the food industry, such as experiences losses and non-optimal profit. Furthermore, several other risks in supply chain strategy are the inadequate identification of risk sources for suppliers, manufacturers, distributors, and consumers. Defective products are at risk in product quality, which cannot be sold on the market [3]. Other factors affect the risk, including problems with stopped production [4], unbalanced employee workloads [5], and improper supplier management [6]. In risk management, the ideal situation is when potential sources of risk in the supply chain are found. Then the management department immediately proposes priority mitigation strategies $[7,8]$. 
To anticipate risks in the food industry, the halal product certification process is the appropriate strategy for adoption. Some studies explain that halal certification aims to ensure product quality that consumers can consume safely [9-11]. Thus, an investigation into the concept of halal products is required in supply chain risk mitigation in the food industry. Inefficient supply chain management can be a source of industry risk if not properly managed. It might affect suppliers, manufacturers, distributors, and consumers. Halal supply chains require strict supervision to follow the standard operating procedures in each production process. It is objected to mitigate risks based on the possibility of loss and potential exposure to losses[12]. A study claims that the halal supply chain can cause losses and dangers from raw materials to finished products [13]. Risk can also be measured based on probability, severity, and impact[14]. Thus, many methods can be used in risk mitigation in supply chain strategies. For halal supply chains, risk mitigation requires grouping halal critical points that occur in every production process. Thus, an approach is needed to risk management in each production process based on the halal concept.

One of the popular models is Supply Chain Operations Reference (SCOR) to maps the supply chain. The SCOR model is a tool for mapping business processes in the supply chain $[15,16]$. One approach in supply chain risk management is the House of Risk. This method is divided into two phases, including HOR phase 1, to determine the priority level of risk causes. HOR phase 2 is a priority in proactive actions considered effective [7]. This model focuses on preventive measures in reducing the possibility of risk agents occurring by identifying risk events. One risk agent can cause several risk events. The HOR can only assign probabilities to risk agents and the severity of the risk. Risk management in the halal supply chain requires accuracy and speed to reduce risk. In addition, the level of risk in the supply chain also needs to be assessed. Probability Impact Matrix (PIM) is one method to assess the level of risk that is easy to apply [17]. The risk assessment of this method is based on probabilities and consequences [18]. The management aims to assess the possibility of each risk and impact based on a predetermined rating scale. Thus, this method can assess risks that have a significant impact and require treatment [19].

Although several risk mitigation studies have been proposed, mitigation research for halal supply chains is very limited. This study proposes the integration of HOR and PIM to mitigate halal supply chain risk based on SCOR. In addition, PIM is offered to assess the level of halal supply chain risk based on SCOR. This study was intended to develop a risk mitigation procedure for the supply chain of halal products using HOR and PIM. The contribution of this research is to enrich knowledge in the field of risk mitigation in the supply chain of halal products by using HOR and PIM. In addition, this research contributes to companies' efforts to improve risk management in the supply chain of halal products.

\section{Methods}

\subsection{Risk Mitigation Procedure in Halal Food Supply Chain}

This study proposed eight stages in risk mitigation in the Halal Food Supply Chain. This study developed the model proposed by Nyoman Pujawan and Geraldin [7]. Details of the stages can be seen in Fig. 1. Stage 1 was the Identification of Critical Points in the Halal Food Supply Chain. At this stage, mapping activities of in halal food supply chain using the Supply Chain Operations Reference (SCOR) was exercised. The activity was organized into five business processes: plan, source, make, deliver, and return. Activity mapping had to pay attention to the halal concept in each activity. In the early stages, 
researchers needed an in-depth study of each activity. It could help in mapping the problems in each business process [20]. Data were obtained through observations, interviews, and questionnaires in each business process [21-23].

At the second stage, the identification of risk events and assessment of severity was conducted. In this section, the identification of risk events was collected in each business process. This risk identification process was carried out by experienced experts in their fields and was also verified by the company [24]. Furthermore, risk events were assessed as severity levels using a scale of 1 (no impact) to 10 (hazardous impact). Furthermore, stage 3 was the identification of risk agents and assessment of occurrence. At this stage, the identification of risk agents was collected for each activity. Furthermore, the risk agent rate of occurrence was assessed from a value of 1 (rarely) to 10 (surely).

Stage 4 determined the Aggregate Risk Potential (ARP) based on the HOR phase 1. At this stage, the experts assessed the correlation between the risk event and the risk agent. The proposed correlation value was on a scale of 0 (no correlation), 1 (low correlation), 3 (medium correlation), and 9 (high correlation). Furthermore, the results of this assessment were used to determine ARP. The ARP was calculated based on the formula presented in equation (1). Where ARPj showed the value of Aggregate Risk Potential at risk agent $j$. Oj was the occurrence value of the risk agent $j$, and $S j$ was the severity value of the risk event $j$. The correlation value between the risk agent and the risk event was denoted as $R_{i j}$. The ranking of the ARP was based on the largest value.

$A R P_{j}=O_{j} \sum_{i} S_{j}+R_{i j}$

Stage 5 was to determine the potential risk agent using Pareto. At this stage, the results of the ARPj calculation were sorted from the largest value to the smallest value. Stage 6 was to assess the level of risk agent using the PIM procedure. Determination of risk agent priority was based on the occurrence and severity assessment of the risk agent. Occurrence assessment was in stage 3, while severity was assessed using a scale of 1 (no impact) to 10 (hazardous impact). Furthermore, these values were converted to the PIM scale in Table 1 . The conversion results were utilized in the risk mapping presented in Fig. 2.

Stage 7 was the determination of proactive action/mitigation based on HOR phase 2 . At this stage, proactive action was done based on the results of discussions with experts. Furthermore, the experts assessed the degree of relationship between proactive action and risk agent values. The results of this assessment were denoted as Eij. In assessing the relationship, this study implemented a scale of 0 (no relationship), 1 (low relationship), 3 (with relationship), and 9 (high relationship). Furthermore, experts evaluated the degree of difficulty $(D k)$. In this study, the Dk assessment was based on a scale of 3 (easy to apply), 4 (somewhat easy to apply), and 5 (difficult to apply). The results of this assessment were then used to calculate the Total Effectiveness of proactive actions (TEk) and the Effectiveness to Difficulty ratio of actions (ETDk). These calculations are presented in equations (2) and (3), respectively. The last stage was to reassess the risk agent when proactive action was applied. This stage was shown to determine the level of effectiveness of proactive action against risk agents. Severity and occurrence values of risk agents were reassessed based on proactive action.

$$
\begin{aligned}
& T E_{k}=\sum_{j} A R P_{j}+E_{i j} \\
& E T D_{k}=T E_{k} / D_{k}
\end{aligned}
$$




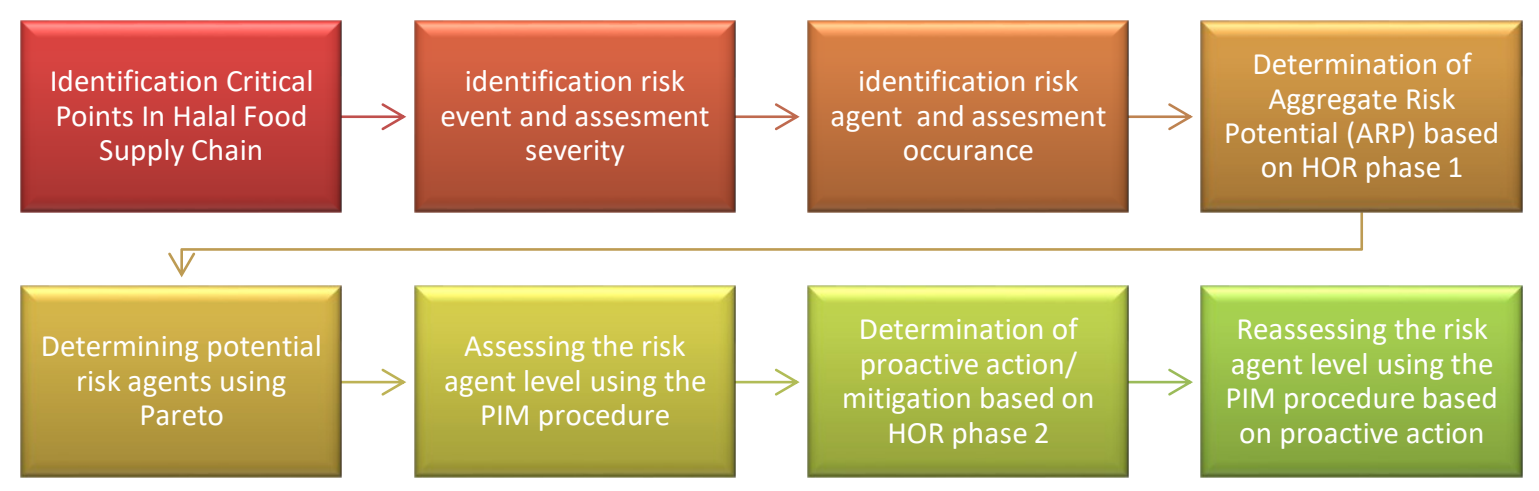

Fig. 1. The stage of risk mitigation

Table 1. Convert of severity and occurrence value to risk level

\begin{tabular}{llll}
\hline Level & Impact (Severity) & Probability (occurance) & Scale \\
\hline 1 - Very Low & $1-4$ & $1-4$ & $0-20 \%$ \\
2 - Low & 5 & 5 & $20-40 \%$ \\
3 - Moderate & 6 & 6 & $40-60 \%$ \\
4 - High & $7-8$ & $7-8$ & $60-80 \%$ \\
4 - Very High & $9-10$ & $9-10$ & $80-100 \%$ \\
\hline
\end{tabular}

\begin{tabular}{|c|c|c|c|c|}
\hline \multirow{2}{*}{$\begin{array}{l}\text { Probability } \\
\text { Rating } \\
\text { (Occurrence) }\end{array}$} & \multicolumn{4}{|c|}{ Impact Rating (Severity) } \\
\hline & 1-Very Low 2 - Low & 3 - Moderate & 4 - High & $\begin{array}{l}5 \text { - Very } \\
\text { High }\end{array}$ \\
\hline 5 - Very High & & & & \\
\hline 4 - High & & & & \\
\hline 3 - Moderate & & & & \\
\hline 2 - Low & & & & \\
\hline 1 - Very Low & & & & \\
\hline
\end{tabular}

Fig. 2. Level of risk based on Probability Impact Matrix

\subsection{Case Study}

This research was designed as a case study on a food company that produces bakeries in Indonesia. Data were collected based on observations, interviews, and questionnaires. Five expert respondents involved in this study consisted of marketing, production, sales, logistics, and human resources experts. The experts were directly involved in 8 stages of research which are presented in Fig. 1. The results of identification and assessment at each stage were considered the result of in-depth discussion among the experts. 


\section{Results and Discussion}

Risk management needs to be carried out in a supply chain strategy to obtain the suitable raw materials to produce finished goods, which are then sent to meet consumer needs. Several studies have explained that risk mitigation involves several processes, methods, and techniques that can help management maximize the consequences of positive events and minimize the consequences of opposite events [25, 26]. Therefore, risk analysis needs to be considered in the management of the food industry. Other studies state that a prevention strategy against risks that are still weak can bring disaster to the industry [27], and giving excessive warnings to avoid risks make various opportunities lost [28]. To overcome these challenges, the management needs to involve an accurate assessment of risk to maximize profits for the industry.

The initial stage was mapping the supply chain strategy by considering the halal concept in the process business. Table 2 shows a review of several studies for determining the critical halal point using the SCOR model framework. The next step was SCOR mapping which involved five aspects (Plan, Source, Make, Deliver, Return). Some of the business units involved in this case can be seen in Fig. 3.

Table 3 describes the events' risk and severity level in business process activities. In this research, there were 31 risk agents in the company. The risk agents and occurrence level can be found in Table 4. Furthermore, the Result of House of Risk (HOR) Phase 1 is displayed in Table 4. Fig. 3 explains the result of the aggregate risk potential compiled using the Pareto Diagram. These results indicated that the risk agent A20 had the largest value, whereas the risk agent A6 produced the smallest value. Therefore, based on the Pareto principle, 16 risk agent priority was selected. To determine the level of risk in each risk agent, this study used the PIM procedure. The results of the risk level assessment for each risk agent are presented in Table 6.

Fig. 4 presents the mapping of risk levels using PIM on risk agents. The results showed that 16 risk agents were categorized as high and medium-high risk. On the other hand, two (2) risk agents (A1 and A2) were classified as moderate. For example, risk agent A20 had an occurrence value of (8) and a severity rating of (6).

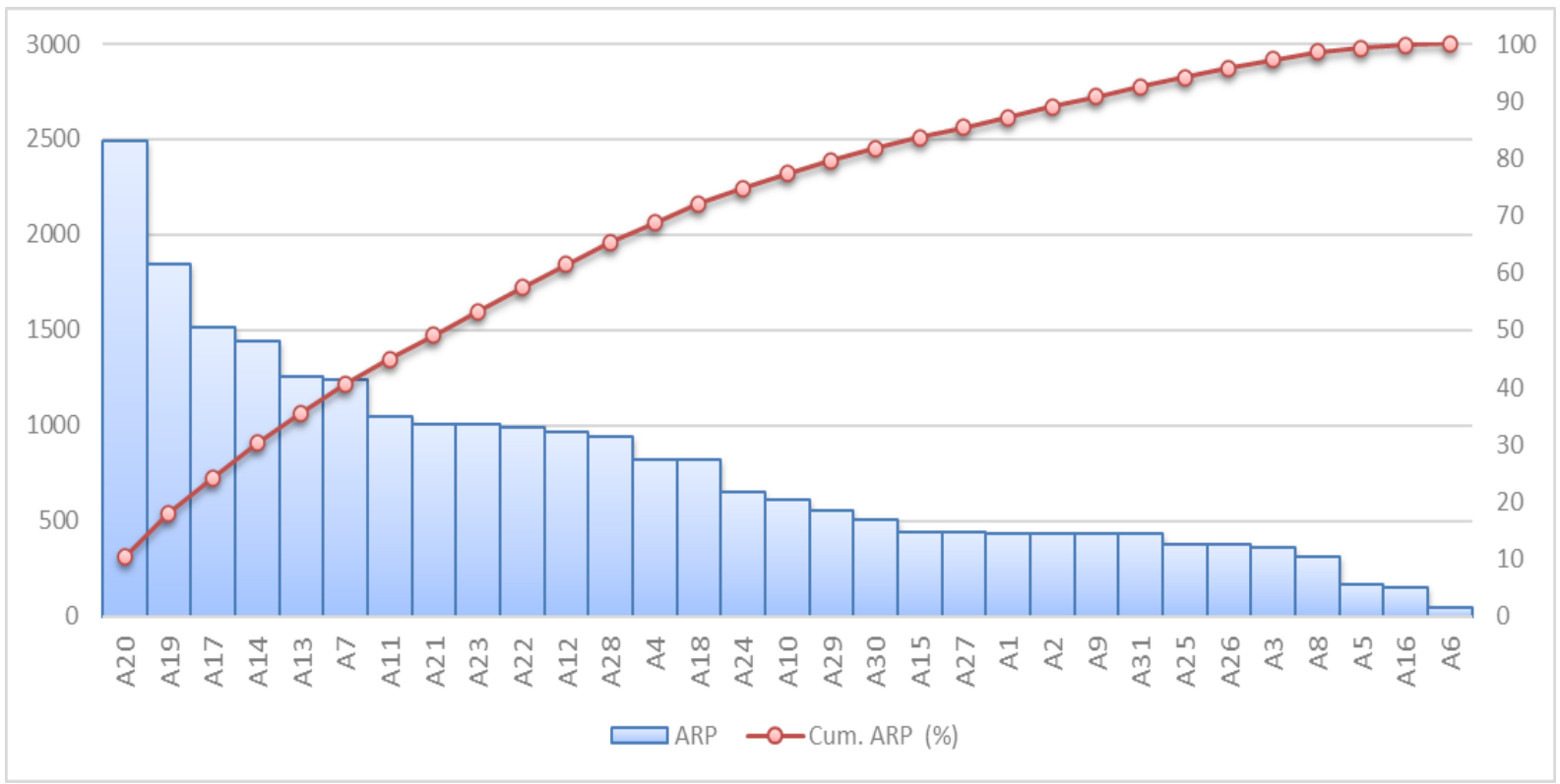

Fig. 3. Aggregate Risk Potential (ARP) 
Based on its PIM and Pareto, proactive action was proposed to mitigate risk. Proactive action and degree of difficulty (Dk) are presented in Table 7. Furthermore, phase 2 of HOR can be seen in Table 8. These results suggested that the greatest value of proactive action was obtained at PA16, and the smallest value was PA8. Based on the proposed proactive action, an assessment of the estimated risk level of the risk agent was also carried out. The risk agent assessment based on proactive action is shown in Table 9 . The results of the risk level assessment of 16 risk agents based on proactive action are shown in Fig. 5. These results indicated that the overall risk agents had decreased risk levels compared to before proactive action.

Table 2. Supply chain strategies for critical halal points based on the SCOR Model

\begin{tabular}{|c|c|c|c|c|c|c|c|}
\hline SCOR & Activity & $\mathrm{A}$ & B & $\mathrm{C}$ & $\mathrm{D}$ & $\mathrm{E}$ & $\mathrm{F}$ \\
\hline \multirow{4}{*}{ Plan } & $\begin{array}{l}\text { Planning of the raw material } \\
\text { procurement }\end{array}$ & $\sqrt{ }$ & & & $\sqrt{ }$ & $\sqrt{ }$ & $\sqrt{ }$ \\
\hline & Production planning & $\sqrt{ }$ & $\sqrt{ }$ & & $\sqrt{ }$ & $\sqrt{ }$ & $\sqrt{ }$ \\
\hline & Distribution planning & $\sqrt{ }$ & & & & $\sqrt{ }$ & \\
\hline & $\begin{array}{l}\text { Planning of machine } \\
\text { maintenance }\end{array}$ & & & $\sqrt{ }$ & & $\sqrt{ }$ & \\
\hline \multirow{3}{*}{ Source } & Supplier selection & $\sqrt{ }$ & & & & & $\sqrt{ }$ \\
\hline & $\begin{array}{l}\text { Selection of halal raw } \\
\text { materials and according to } \\
\text { standards }\end{array}$ & $\sqrt{ }$ & & & $\sqrt{ }$ & $\sqrt{ }$ & \\
\hline & $\begin{array}{l}\text { The process of procuring raw } \\
\text { materials }\end{array}$ & $\sqrt{ }$ & & & $\sqrt{ }$ & & \\
\hline \multirow{4}{*}{ Make } & $\begin{array}{l}\text { Production execution according } \\
\text { to plan }\end{array}$ & $\sqrt{ }$ & $\sqrt{ }$ & & & & \\
\hline & $\begin{array}{l}\text { Checking the halalness of the } \\
\text { finished product }\end{array}$ & $\sqrt{ }$ & & $\sqrt{ }$ & & $\sqrt{ }$ & \\
\hline & $\begin{array}{l}\text { Checking the quality of the } \\
\text { finished product }\end{array}$ & $\sqrt{ }$ & $\sqrt{ }$ & & $\sqrt{ }$ & & \\
\hline & Storage of finished products & $\sqrt{ }$ & $\sqrt{ }$ & & & $\sqrt{ }$ & \\
\hline \multirow{4}{*}{ Deliver } & Delivery of goods & $\sqrt{ }$ & & & & $\sqrt{ }$ & \\
\hline & $\begin{array}{l}\text { Ensure that goods are not } \\
\text { contaminated which is not } \\
\text { halal }\end{array}$ & $\sqrt{ }$ & & & $\sqrt{ }$ & $\sqrt{ }$ & $\sqrt{ }$ \\
\hline & $\begin{array}{l}\text { Product availability data } \\
\text { information }\end{array}$ & & $\sqrt{ }$ & & & & \\
\hline & Selection of logistic providers & $\sqrt{ }$ & & & & & $\sqrt{ }$ \\
\hline \multirow[b]{2}{*}{ Return } & $\begin{array}{l}\text { Return the product to the } \\
\text { supplier }\end{array}$ & & $\sqrt{ }$ & & & $\sqrt{ }$ & \\
\hline & $\begin{array}{l}\text { Handling of returned products } \\
\text { by customers }\end{array}$ & & $\sqrt{ }$ & & & $\sqrt{ }$ & \\
\hline
\end{tabular}

Note : $\mathrm{A}=$ research by Nukeriana [29]; $\mathrm{B}=$ research by Neio Demirci, et al. [30]; $\mathrm{C}=$ research by Lau, et al. [31]; D = research by Faridah [32]; E = research by Jannah [33]; F= research by Atma, et al. [34]. 
Table 3. Risk Event and Severity Level

\begin{tabular}{|c|c|c|c|c|}
\hline SCOR & Activity & Risk Event & Code & $\begin{array}{l}\text { Severity } \\
\text { (Si) }\end{array}$ \\
\hline \multirow{5}{*}{ Plan } & $\begin{array}{l}\text { Planning of the raw } \\
\text { material procurement }\end{array}$ & Late arrival of raw materials & E1 & 6 \\
\hline & \multirow{2}{*}{ Production planning } & $\begin{array}{l}\text { The change in production plans } \\
\text { suddenly }\end{array}$ & E2 & 6 \\
\hline & & $\begin{array}{l}\text { Errors in planning production } \\
\text { quantities }\end{array}$ & E3 & 7 \\
\hline & Distribution planning & Delay in providing finished products & $\mathrm{E} 4$ & 7 \\
\hline & $\begin{array}{l}\text { Planning of machine } \\
\text { maintenance }\end{array}$ & $\begin{array}{l}\text { Machine maintenance planning } \\
\text { schedule errors }\end{array}$ & E5 & 7 \\
\hline \multirow{6}{*}{ Source } & $\begin{array}{l}\text { Supplier selection and } \\
\text { contract }\end{array}$ & Miss communication with suppliers & E6 & 8 \\
\hline & \multirow{2}{*}{$\begin{array}{l}\text { Selection of halal raw } \\
\text { materials and according } \\
\text { to standards }\end{array}$} & $\begin{array}{l}\text { The difficulty in getting raw materials } \\
\text { according to standards }\end{array}$ & E7 & 7 \\
\hline & & $\begin{array}{l}\text { The low ability of suppliers to meet } \\
\text { demand in quality }\end{array}$ & E8 & 7 \\
\hline & \multirow{3}{*}{$\begin{array}{l}\text { The process of procuring } \\
\text { raw materials }\end{array}$} & Late arrival of raw materials & E9 & 7 \\
\hline & & $\begin{array}{l}\text { The supplier cannot meet the total raw } \\
\text { material requirements }\end{array}$ & E10 & 6 \\
\hline & & $\begin{array}{l}\text { Logistics error in raw material } \\
\text { inspection }\end{array}$ & E11 & 7 \\
\hline \multirow{8}{*}{ Make } & \multirow{5}{*}{$\begin{array}{l}\text { Production execution } \\
\text { according to plan }\end{array}$} & The insufficient stock of raw materials & E12 & 7 \\
\hline & & $\begin{array}{l}\text { The insufficient stock of supporting } \\
\text { materials }\end{array}$ & E13 & 7 \\
\hline & & The delay in the production process & E14 & 7 \\
\hline & & The demand from consumers suddenly & E15 & 6 \\
\hline & & Production defect & E16 & 7 \\
\hline & $\begin{array}{l}\text { Checking the halalness } \\
\text { of the finished product }\end{array}$ & $\begin{array}{l}\text { Ensure that there are no contaminated } \\
\text { materials and tools that are haram }\end{array}$ & E17 & 6 \\
\hline & $\begin{array}{l}\text { Checking the quality of } \\
\text { finished product }\end{array}$ & Less thorough quality inspection & E18 & 7 \\
\hline & $\begin{array}{l}\text { Storage of finished } \\
\text { products }\end{array}$ & The damaged product in storage & E19 & 6 \\
\hline \multirow{5}{*}{ Deliver } & $\begin{array}{l}\text { Selection of logistic } \\
\text { providers }\end{array}$ & $\begin{array}{l}\text { Unilateral cancellation from logistic } \\
\text { provider }\end{array}$ & E20 & 8 \\
\hline & \multirow{2}{*}{ Delivery of goods } & Late arrival of raw materials & $\mathrm{E} 21$ & 8 \\
\hline & & Product damaged in transit & $\mathrm{E} 22$ & 7 \\
\hline & $\begin{array}{l}\text { Ensure that goods are } \\
\text { not contaminated which } \\
\text { is not halal }\end{array}$ & $\begin{array}{l}\text { Check the halalness of the raw material } \\
\text { storage area periodically }\end{array}$ & $\mathrm{E} 23$ & 6 \\
\hline & $\begin{array}{l}\text { Product availability } \\
\text { data information }\end{array}$ & $\begin{array}{l}\text { An error occurred with the product } \\
\text { availability number }\end{array}$ & $\mathrm{E} 24$ & 7 \\
\hline \multirow{3}{*}{ Return } & \multirow{2}{*}{$\begin{array}{l}\text { Return the finished } \\
\text { product from the } \\
\text { consumers }\end{array}$} & $\begin{array}{l}\text { Delay in returning products to } \\
\text { consumers }\end{array}$ & $\mathrm{E} 25$ & 8 \\
\hline & & There is an additional fee & E26 & 7 \\
\hline & $\begin{array}{l}\text { Return the product to } \\
\text { the supplier }\end{array}$ & $\begin{array}{l}\text { Late replacement of raw materials to } \\
\text { suppliers }\end{array}$ & $\mathrm{E} 27$ & 8 \\
\hline
\end{tabular}


Table 4. Risk Agent and Level of Occurrence

\begin{tabular}{|c|c|c|c|}
\hline SCOR & Risk Agent & Code & Occurrence $\left(\mathrm{O}_{j}\right)$ \\
\hline \multirow{8}{*}{ Plan } & The uncertainty of delivery time by expedition & A1 & 6 \\
\hline & The stock of goods is empty & A2 & 6 \\
\hline & Lack of supply of raw materials in warehouses & A3 & 5 \\
\hline & $\begin{array}{l}\text { The uncertainty of the number of orders from } \\
\text { consumers }\end{array}$ & $\mathrm{A} 4$ & 7 \\
\hline & $\begin{array}{l}\text { Supplier's inability to provide raw materials in a } \\
\text { quantity }\end{array}$ & A5 & 7 \\
\hline & Poor warehouse management & $\mathrm{A} 6$ & 7 \\
\hline & Human error & A7 & 6 \\
\hline & Machine maintenance planning errors & A8 & 5 \\
\hline \multirow{8}{*}{ Source } & Less strong agreements/contracts with suppliers & A9 & 6 \\
\hline & Raw materials below standard quality & A10 & 7 \\
\hline & $\begin{array}{l}\text { Incompatibility of price with the quality of raw } \\
\text { materials }\end{array}$ & A11 & 7 \\
\hline & Natural factors & A12 & 7 \\
\hline & Inadequate conditions of transportation & A13 & 7 \\
\hline & Scarcity of raw materials & $\mathrm{A} 14$ & 8 \\
\hline & Quality inspection errors during the loading process & $\mathrm{A} 15$ & 7 \\
\hline & Not in accordance with the SOP & A16 & 7 \\
\hline \multirow{4}{*}{ Make } & Poor warehouse management & A17 & 8 \\
\hline & The delay of the production process & A18 & 7 \\
\hline & Workers do not focus, and they are not conscientious & A19 & 8 \\
\hline & Workers do not have special skills & $\mathrm{A} 20$ & 8 \\
\hline \multirow{7}{*}{ Deliver } & The void of raw material & $\mathrm{A} 21$ & 7 \\
\hline & Bad weather & $\mathrm{A} 22$ & 6 \\
\hline & The difficulty for getting raw materials & A23 & 7 \\
\hline & Road conditions are not good & $\mathrm{A} 24$ & 7 \\
\hline & The product packaging is not good & $\mathrm{A} 25$ & 6 \\
\hline & $\begin{array}{l}\text { There is no special team to check the halal of the } \\
\text { area }\end{array}$ & $\mathrm{A} 26$ & 7 \\
\hline & Data are not updated & $\mathrm{A} 27$ & 7 \\
\hline \multirow{4}{*}{ Return } & The damaged means of transportation & A28 & 7 \\
\hline & Bad weather & $\mathrm{A} 29$ & 6 \\
\hline & The delay in handling incoming material & A30 & 7 \\
\hline & $\begin{array}{l}\text { Weaknesses in the memorandum of agreement with } \\
\text { suppliers }\end{array}$ & A31 & 6 \\
\hline
\end{tabular}


Table 5. HOR Phase 1

Code

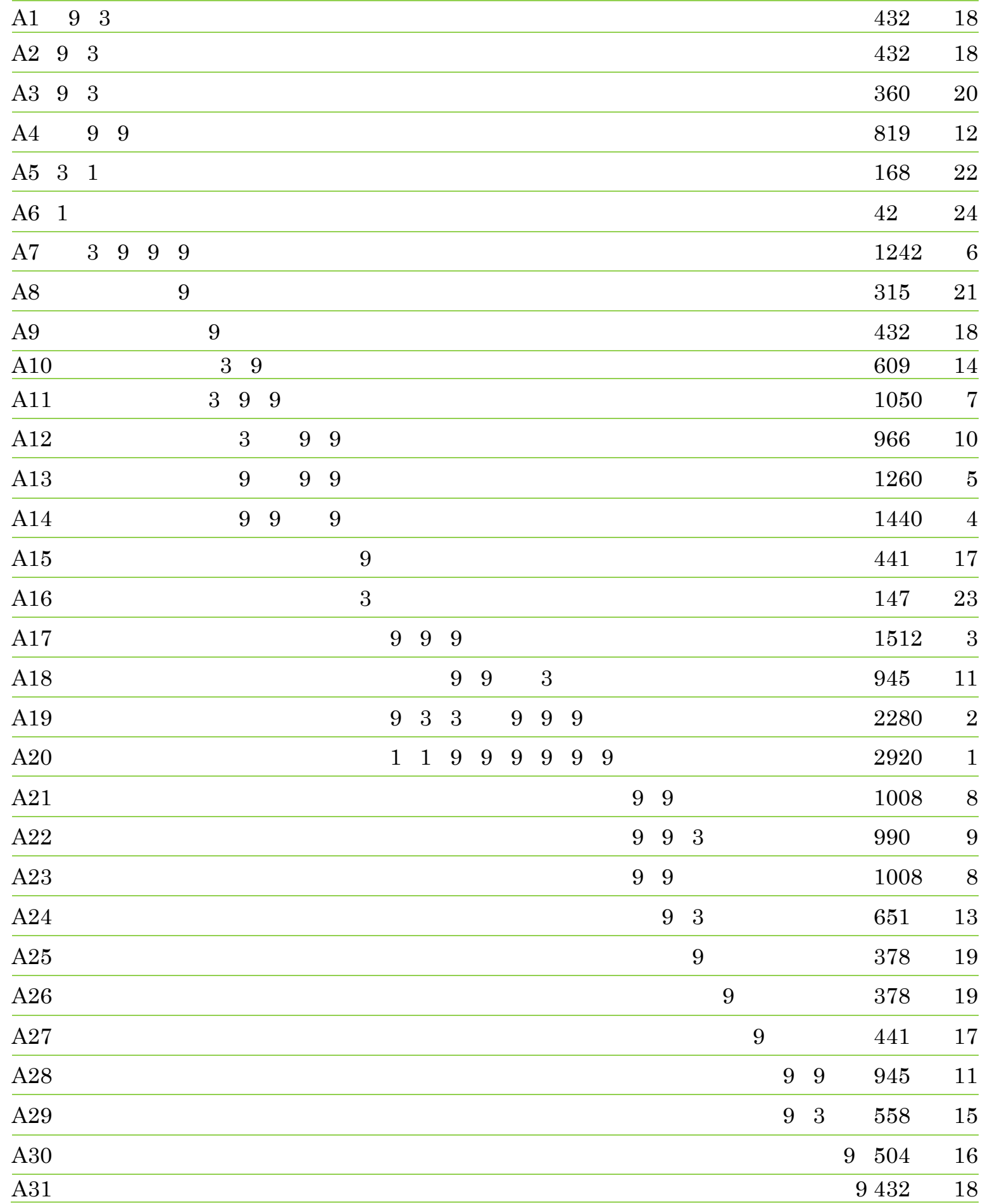


Table 6. Risk Agent Priority

\begin{tabular}{|c|c|c|c|c|c|}
\hline SCOR & \multicolumn{2}{|c|}{ Risk Agent } & Code & $(\mathrm{Oj})$ & $(\mathrm{Sj})$ \\
\hline \multirow{4}{*}{ Plan } & \multicolumn{2}{|c|}{ The uncertainty of delivery time by expedition } & $\mathrm{A} 1$ & 6 & 6 \\
\hline & \multicolumn{2}{|c|}{ The stock of goods is empty } & $\mathrm{A} 2$ & 6 & 6 \\
\hline & \multicolumn{2}{|c|}{ The uncertainty of the number of orders from consumers } & $\mathrm{A} 4$ & 7 & 6 \\
\hline & \multicolumn{2}{|c|}{ Human error } & A7 & 6 & 7 \\
\hline \multirow{4}{*}{ Source } & \multicolumn{2}{|c|}{ Incompatibility of price with the quality of raw materials } & A11 & 7 & 7 \\
\hline & \multicolumn{2}{|c|}{ Natural factors } & $\mathrm{A} 12$ & 7 & 7 \\
\hline & \multicolumn{2}{|c|}{ Inadequate conditions of transportation } & A13 & 7 & 7 \\
\hline & \multicolumn{2}{|c|}{ Scarcity of raw materials } & $\mathrm{A} 14$ & 8 & 6 \\
\hline \multirow[b]{2}{*}{ Make } & \multicolumn{2}{|c|}{ Workers do not focus, and they are not conscientious } & A19 & 8 & 7 \\
\hline & \multicolumn{2}{|c|}{ Workers do not have special skills } & $\mathrm{A} 20$ & 8 & 6 \\
\hline \multirow{4}{*}{ Deliver } & \multicolumn{2}{|c|}{ The void of raw material } & $\mathrm{A} 21$ & 7 & 8 \\
\hline & \multicolumn{2}{|c|}{ Bad weather } & $\mathrm{A} 22$ & 6 & 8 \\
\hline & \multicolumn{2}{|c|}{ The difficulty for getting raw materials } & $\mathrm{A} 23$ & 7 & 7 \\
\hline & \multicolumn{2}{|c|}{ Road conditions are not good } & $\mathrm{A} 24$ & 7 & 8 \\
\hline \multirow[b]{2}{*}{ Return } & \multicolumn{2}{|c|}{ The damaged means of transportation } & $\mathrm{A} 28$ & 7 & 8 \\
\hline & \multicolumn{2}{|c|}{ Bad weather } & $\mathrm{A} 29$ & 6 & 7 \\
\hline \multicolumn{6}{|c|}{ Table 7. Proactive Action and Degree of Difficulty $(D k)$} \\
\hline SCOR & \multicolumn{2}{|c|}{ Code Proactive action } & & & $\mathrm{Dk}$ \\
\hline & PA1 & Looking for alternative routes of material delivery & & & 3 \\
\hline & PA2 & Conducting additional stock & & & 4 \\
\hline & PA3 & The user and logistics must coordinate & & & 3 \\
\hline & PA4 & The suppliers and logistics must coordinate & & & 3 \\
\hline Plan & PA5 & $\begin{array}{l}\text { Determine the inventory management policies foll } \\
\text { conditions }\end{array}$ & compan & & 3 \\
\hline & PA6 & Forecasting sales & & & 3 \\
\hline & PA7 & Do regular training for employees & & & 4 \\
\hline & PA8 & Create a structured machine maintenance schedul & & & 3 \\
\hline & PA9 & Add the number of engineers to check machines & & & 5 \\
\hline & PA10 & Looking for suppliers from outside the region or ab & & & 3 \\
\hline & PA11 & Add the number of raw material orders & & & 3 \\
\hline Source & PA12 & Do service and regularly check on transportation e & ment & & 3 \\
\hline & PA13 & Looking for substitutes that resemble raw materia & & & 4 \\
\hline & PA14 & Carry out the training regularly & & & 4 \\
\hline Make & PA15 & Create check sheets in each work area & & & 5 \\
\hline & PA16 & Apply rewards and punishments to workers & & & 4 \\
\hline & PA17 & Strengthen the memorandum of agreement with $t$ & pplier & & 5 \\
\hline & PA18 & Looking for other alternatives that resemble raw $\mathrm{n}$ & ials & & 4 \\
\hline Deliver & PA19 & Provide suitable transportation & & & 4 \\
\hline & PA20 & Create the long-term proudction plan (MRP) & & & 5 \\
\hline & PA21 & Ensure the feasibility of the means of transportati & be used & & 4 \\
\hline Return & PA22 & Maintenance of transportation equipment regular & & & 4 \\
\hline & PA23 & Do packaging on the product neatly and strongly & & & 5 \\
\hline
\end{tabular}


Table 8. HOR Phase 2

\begin{tabular}{|c|c|c|c|c|c|c|c|c|c|c|c|c|c|c|c|c|c|c|}
\hline Code & $\mathrm{A} 1$ & A2 & A4 & A7 & A11 & A12 & A13 & A14 & A19 & A20 & A21 & $\mathrm{A} 22$ & A23 & A24 & A28 & A 29 & $\mathrm{ETD}_{\mathrm{k}}$ & Rank \\
\hline $\mathrm{PA} 1$ & 9 & & & & & & & & & & & & & & & & 1296 & 19 \\
\hline PA 2 & 9 & 9 & 9 & & & & & & & & & & & & & & 3787 & 9 \\
\hline PA 3 & & 9 & 9 & & & & & & & & & & & & & & 3753 & 11 \\
\hline PA 4 & 3 & 9 & 9 & & & & & & & & & & & & & & 4185 & 7 \\
\hline PA 5 & & 9 & 9 & & & & & & & & & & & & & & 3753 & 11 \\
\hline PA 6 & & 3 & 9 & & & & & & & & & & & & & & 2889 & 14 \\
\hline PA 7 & & & & 9 & & & & & & & & & & & & & 2795 & 15 \\
\hline PA 8 & & & & 1 & & & & & & & & & & & & & 414 & 22 \\
\hline PA 9 & & & & 3 & & & & & & & & & & & & & 745 & 21 \\
\hline PA10 & & & & & 9 & & & 3 & & & & & & & & & 4590 & 5 \\
\hline PA11 & & & & & & 9 & & 9 & & & & & & & & & 7218 & 3 \\
\hline PA12 & & & & & & & 9 & & & & & & & & & & 3780 & 10 \\
\hline PA13 & & & & & 3 & & & 9 & & & & & & & & & 4028 & 8 \\
\hline PA14 & & & & & & & & & 9 & 3 & & & & & & & 6024 & 4 \\
\hline PA15 & & & & & & & & & 9 & 9 & & & & & & & 7805 & 2 \\
\hline PA16 & & & & & & & & & 9 & 9 & & & & & & & 9756 & 1 \\
\hline PA17 & & & & & & & & & & & 9 & & & & & & 1814 & 18 \\
\hline PA18 & & & & & & & & & & & 9 & & 9 & & & & 4536 & 6 \\
\hline PA19 & & & & & & & & & & & & 9 & & 9 & & & 3692 & 12 \\
\hline PA20 & & & & & & & & & & & 3 & & 9 & & & & 2419 & 17 \\
\hline PA21 & & & & & & & & & & & & & & & 9 & 9 & 3382 & 13 \\
\hline PA22 & & & & & & & & & & & & & & & 9 & 3 & 2545 & 16 \\
\hline PA23 & & & & & & & & & & & & & & & & 9 & 1004 & 20 \\
\hline
\end{tabular}

Table 9. Risk Agent Assessment Based on the Proactive Action

\begin{tabular}{|c|c|c|c|c|c|}
\hline SCOR & Rank & $\begin{array}{l}\text { Risk Agent } \\
\text { Code }\end{array}$ & $\mathrm{Oj}$ & $\mathrm{Si}$ & $\begin{array}{c}\text { Proactive Action } \\
\text { Code }\end{array}$ \\
\hline \multirow{9}{*}{ Plan } & \multirow{3}{*}{1} & \multirow{3}{*}{ A7 } & \multirow{3}{*}{5} & \multirow{3}{*}{4} & PA7 \\
\hline & & & & & PA8 \\
\hline & & & & & PA9 \\
\hline & 2 & A4 & 6 & 6 & PA6 \\
\hline & \multirow{2}{*}{3} & \multirow{2}{*}{$\mathrm{A} 1$} & \multirow[b]{2}{*}{2} & \multirow[b]{2}{*}{2} & PA1 \\
\hline & & & & & $\mathrm{PA} 2$ \\
\hline & \multirow{3}{*}{4} & \multirow{3}{*}{ A2 } & \multirow{3}{*}{3} & \multirow{3}{*}{2} & PA3 \\
\hline & & & & & PA4 \\
\hline & & & & & PA5 \\
\hline \multirow{4}{*}{ Source } & 1 & A14 & 5 & 2 & PA13 \\
\hline & 2 & A13 & 6 & 5 & PA12 \\
\hline & 3 & A11 & 5 & 3 & PA10 \\
\hline & 4 & $\mathrm{~A} 12$ & 6 & 3 & PA11 \\
\hline \multirow{3}{*}{ Make } & 1 & $\mathrm{~A} 20$ & 2 & 3 & PA16 \\
\hline & \multirow{2}{*}{2} & \multirow{2}{*}{ A19 } & \multirow{2}{*}{4} & \multirow{2}{*}{5} & PA14 \\
\hline & & & & & PA15 \\
\hline \multirow{4}{*}{ Deliver } & 1 & $\mathrm{~A} 21$ & 2 & 3 & PA17 \\
\hline & 2 & $\mathrm{~A} 23$ & 5 & 3 & PA18 \\
\hline & 3 & $\mathrm{~A} 22$ & 3 & 5 & PA19 \\
\hline & 4 & $\mathrm{~A} 24$ & 5 & 2 & PA20 \\
\hline \multirow{3}{*}{ Return } & 1 & A28 & 2 & 3 & PA21 \\
\hline & \multirow{2}{*}{2} & \multirow{2}{*}{$\mathrm{A} 29$} & \multirow{2}{*}{3} & \multirow{2}{*}{4} & PA22 \\
\hline & & & & & PA23 \\
\hline
\end{tabular}




\begin{tabular}{|c|c|c|c|c|c|}
\hline \multirow{2}{*}{$\begin{array}{l}\text { Probability Rating } \\
\text { (Occurrence) }\end{array}$} & \multicolumn{5}{|c|}{ Impact Rating (Severity) } \\
\hline & 1-Very Low & 2 - Low & 3 - Moderate & 4 - High & 5 - Very High \\
\hline \multicolumn{6}{|l|}{5 - Very High } \\
\hline 4 - High & & & $\begin{array}{l}\text { A } 4, \text { A } 14, \\
\text { A } 20\end{array}$ & $\begin{array}{l}\text { A13, A11, } \\
\text { A12, A21, } \\
\text { A23, A24, } \\
\text { A28 }\end{array}$ & \\
\hline 3 - Moderate & & & $\mathrm{A} 1, \mathrm{~A} 2$ & $\begin{array}{l}\mathrm{A} 7, \mathrm{~A} 18, \\
\mathrm{~A} 22, \mathrm{~A} 29\end{array}$ & \\
\hline \multicolumn{6}{|l|}{2 - Low } \\
\hline 1 - Very Low & & & & & \\
\hline
\end{tabular}

\begin{tabular}{|c|c|c|c|c|c|c|}
\hline No & Risk Agent & Code & $\begin{array}{l}\text { Risk } \\
\text { Impact }\end{array}$ & $\begin{array}{l}\text { Risk } \\
\text { Probability }\end{array}$ & Rank & Level risk \\
\hline 1 & $\begin{array}{l}\text { Workers do not have special } \\
\text { skills }\end{array}$ & $\mathrm{A} 20$ & M & $\mathrm{H}$ & 1 & \\
\hline 2 & $\begin{array}{l}\text { Workers do not focus, and } \\
\text { they are not conscientious }\end{array}$ & A19 & $\mathrm{H}$ & $\mathrm{H}$ & 2 & \\
\hline 3 & Scarcity of raw materials & $\mathrm{A} 14$ & $\mathrm{M}$ & $\mathrm{H}$ & 3 & \\
\hline 4 & $\begin{array}{l}\text { Inadequate conditions of } \\
\text { transportation }\end{array}$ & $\mathrm{A} 13$ & $\mathrm{H}$ & $\mathrm{H}$ & 4 & \\
\hline 5 & Human error & A7 & $\mathrm{H}$ & $\mathrm{M}$ & 5 & \\
\hline 6 & $\begin{array}{l}\text { Incompatibility of price } \\
\text { with the quality of raw } \\
\text { materials }\end{array}$ & A11 & $\mathrm{H}$ & $\mathrm{H}$ & 6 & \\
\hline 7 & The void of raw material & $\mathrm{A} 21$ & $\mathrm{H}$ & $\mathrm{H}$ & 7 & \\
\hline 8 & $\begin{array}{l}\text { Difficulty for getting raw } \\
\text { materials }\end{array}$ & $\mathrm{A} 23$ & $\mathrm{H}$ & $\mathrm{H}$ & 8 & \\
\hline 9 & Bad weather & $\mathrm{A} 22$ & $\mathrm{H}$ & $\mathrm{M}$ & 9 & \\
\hline 10 & Natural factors & A12 & $\mathrm{H}$ & $\mathrm{H}$ & 10 & \\
\hline 11 & $\begin{array}{l}\text { The damaged means of } \\
\text { transportation }\end{array}$ & $\mathrm{A} 28$ & $\mathrm{H}$ & $\mathrm{H}$ & 11 & \\
\hline 12 & $\begin{array}{l}\text { The uncertainty of the } \\
\text { number of orders from } \\
\text { consumers }\end{array}$ & $\mathrm{A} 4$ & M & $\mathrm{H}$ & 12 & \\
\hline 13 & $\begin{array}{l}\text { Road conditions are not } \\
\text { good }\end{array}$ & $\mathrm{A} 24$ & $\mathrm{H}$ & $\mathrm{H}$ & 13 & \\
\hline 14 & Bad weather & $\mathrm{A} 29$ & $\mathrm{H}$ & $\mathrm{M}$ & 14 & \\
\hline 15 & $\begin{array}{l}\text { The uncertainty of delivery } \\
\text { time by expedition }\end{array}$ & A1 & $\mathrm{M}$ & $\mathrm{M}$ & 15 & \\
\hline 16 & The stock of good is empty & $\mathrm{A} 2$ & M & $\mathrm{M}$ & 16 & \\
\hline
\end{tabular}

Fig. 4. Risk Level for Risk Agent Based on the PIM 


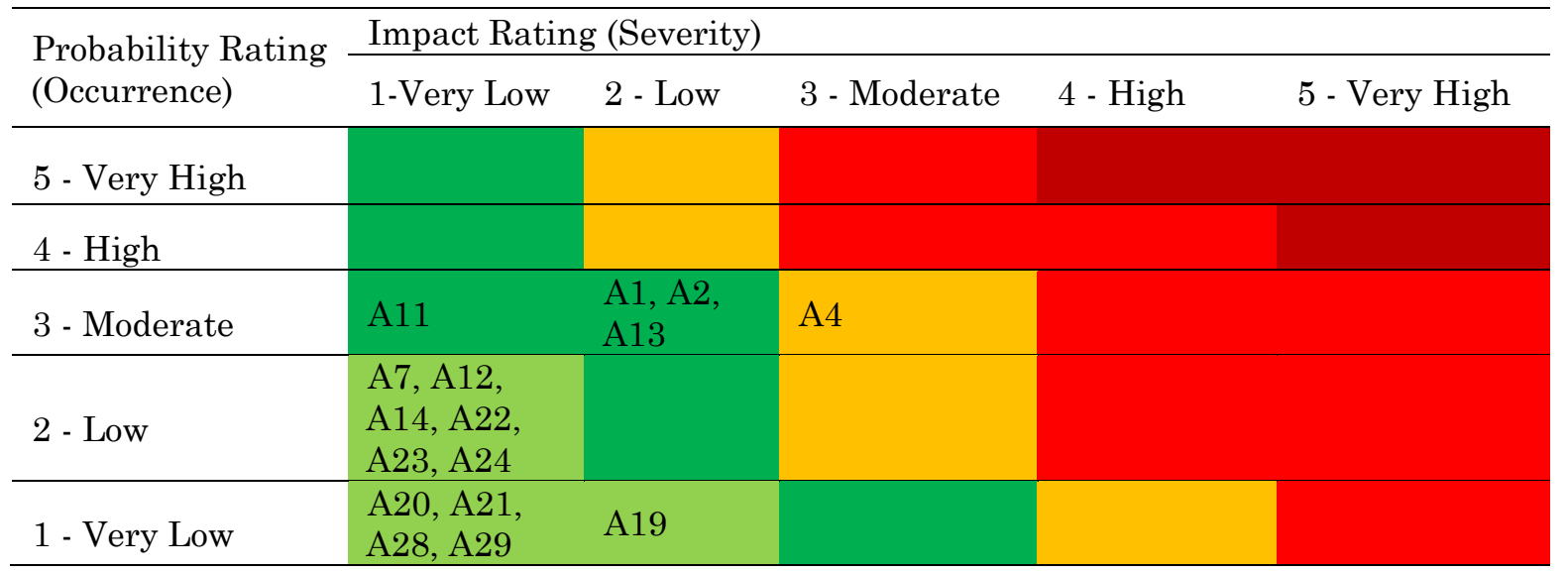

\begin{tabular}{|c|c|c|c|c|c|c|}
\hline No & Risk Factors & Code & $\begin{array}{l}\text { Risk } \\
\text { Impact }\end{array}$ & $\begin{array}{l}\text { Risk } \\
\text { Probability }\end{array}$ & Rank & $\begin{array}{l}\text { Level } \\
\text { risk }\end{array}$ \\
\hline 1 & $\begin{array}{l}\text { Workers do not have special } \\
\text { skills }\end{array}$ & $\mathrm{A} 20$ & VL & VL & 1 & \\
\hline 2 & $\begin{array}{l}\text { Workers do not focus, and } \\
\text { they are not conscientious }\end{array}$ & A19 & $\mathrm{L}$ & $\mathrm{VL}$ & 2 & \\
\hline 3 & Scarcity of raw materials & A14 & $\mathrm{VL}$ & $\mathrm{L}$ & 3 & \\
\hline 4 & $\begin{array}{l}\text { Inadequate conditions of } \\
\text { transportation }\end{array}$ & A13 & $\mathrm{L}$ & M & 4 & \\
\hline 5 & Human error & $\mathrm{A} 7$ & $\mathrm{VL}$ & $\mathrm{L}$ & 5 & \\
\hline 6 & $\begin{array}{l}\text { Incompatibility of price with } \\
\text { the quality of raw materials }\end{array}$ & A11 & VL & $\mathrm{M}$ & 6 & \\
\hline 7 & The void of raw material & $\mathrm{A} 21$ & $\mathrm{VL}$ & $\mathrm{VL}$ & 7 & \\
\hline 8 & $\begin{array}{l}\text { Difficulty for getting raw } \\
\text { materials }\end{array}$ & $\mathrm{A} 23$ & VL & $\mathrm{L}$ & 8 & \\
\hline 9 & Bad weather & $\mathrm{A} 22$ & $\mathrm{VL}$ & $\mathrm{L}$ & 9 & \\
\hline 10 & Natural factors & $\mathrm{A} 12$ & $\mathrm{VL}$ & $\mathrm{L}$ & 10 & \\
\hline 11 & $\begin{array}{l}\text { The damaged means of } \\
\text { transportation }\end{array}$ & $\mathrm{A} 28$ & VL & VL & 11 & \\
\hline 12 & $\begin{array}{l}\text { The uncertainty of the } \\
\text { number of orders from } \\
\text { consumers }\end{array}$ & $\mathrm{A} 4$ & $\mathrm{M}$ & $\mathrm{M}$ & 12 & \\
\hline 13 & Road conditions are not good & $\mathrm{A} 24$ & $\mathrm{VL}$ & $\mathrm{L}$ & 13 & \\
\hline 14 & Bad weather & $\mathrm{A} 29$ & $\mathrm{VL}$ & $\mathrm{VL}$ & 14 & \\
\hline 15 & $\begin{array}{l}\text { The uncertainty of delivery } \\
\text { time by expedition }\end{array}$ & A1 & $\mathrm{L}$ & $\mathrm{M}$ & 15 & \\
\hline 16 & The stock of good is empty & $\mathrm{A} 2$ & $\mathrm{~L}$ & M & 16 & \\
\hline
\end{tabular}

Fig. 5. Probability Impact Matrix for Risk Agent Priority Based on the Proactive Action

This study implied that integrating the house of risk method and the probability impact matrix can solve the appointed problem. Halal supply chain requires risk mitigation to ensure halal quality standards in Indonesian produce products. Previous 
research has implemented a house of risk in the halal supply chain in a small-medium enterprise [35] [36]. The results of the research found risk agents and proactive actions to mitigate risk. However, this research was still limited in grouping risk levels to speed up the risk mitigation process. Then, this case study integrated the probability impact matrix to measure the level of probability and impact on risk. The probability impact matrix method is widely used for project management cases in accelerating project work [37]. Therefore, modifying the probability impact matrix in the house of risk can provide accuracy and speed for halal products in mitigating risks to improve service to consumers.

\section{Conclusion}

This study indicated that the mapping of supply chain strategies in halal food based on the SCOR model had provided an overview of the business processes of suppliers, manufacturers, logistics, and consumers. This study identified 27 risk events and 31 risk agents. HOR Phase 1 concluded that the highest risk occurred to the employees who did not have special skills to carry out their work. Then, phase 2 concluded that the best proposal for making effective improvements by business managers was to apply a reward and punishment system to employees. Then, each phase of the HOR was integrated with the probability impact matrix to determine risk priorities in risk mitigation. The implication of this research is in the form of a recommendation to the food industry management in mitigating the sources of risk in each business process. In addition, further study is suggested to adjust the risks that have been found with halal certification regulations in Indonesia.

\section{Data Availability}

All data generated or analyzed during this study are included in this article.

\section{Declarations}

Author contribution: Fitra Lestari contributes to conceptualization, methodology, data collection, validation, formal analysis, writing (original draft preparation, review, and editing), and funding acquisition. Ahmad Mas'ari contributes to conceptualization, validation, and investigation. Silfia Meilani contributes to methodology, data collection, software, writing (original draft preparation), and project administration. Irsan Nuari Riandika contributes to validation, investigation, writing (review and editing). Abu Bakar Abdul Hamid contributes to conceptualization, writing (review and editing), and validation. All authors read and approved the final paper.

Funding statement: This research was supported by the Faculty of Science and Technology in UIN Sultan Syarif Kasim Riau.

Conflict of interest: The authors declare no conflict of interest.

Additional information: No additional information is available for this paper.

\section{Acknowledgment}

The researcher would like to thank the UIN Sultan Syarif Kasim Riau for supporting the research. In addition, the researcher would also like to extend their gratitude to the Center of Islamic Data Science and Continues Improvement (CIDSCI) for providing the facilities. 


\section{References}

[1] R. Zhong, X. Xu, and L. Wang, "Food supply chain management: systems, implementations, and future research," Industrial Management \& Data Systems, vol. 117, no. 9, pp. 2085-2114, 2017. https://doi.org/10.1108/IMDS-09-2016-0391.

[2] Y. He, H. Huang, D. Li, C. Shi, and S. J. Wu, "Quality and Operations Management in Food Supply Chains: A Literature Review," Journal of Food Quality, vol. 2018, p. 7279491, 2018. https://doi.org/10.1155/2018/7279491.

[3] L. C. Hoe and S. Mansori, "The effects of product quality on customer satisfaction and loyalty: Evidence from Malaysian engineering industry," International Journal of Industrial Marketing, vol. 3, no. 1, p. 20, 2018. https://doi.org/10.5296/ijim.v3i1.13959.

[4] G. C. Dias, C. T. Hernandez, and U. R. d. Oliveira, "Supply chain risk management and risk ranking in the automotive industry," Gestão \& Produção, vol. 27, p. 21, 2020. https://doi.org/10.1590/0104-530X3800-20.

[5] S. Wruck, I. F. A. Vis, and J. Boter, "Risk control for staff planning in e-commerce warehouses," International Journal of Production Research, vol. 55, no. 21, pp. 6453-6469, 2017. https://doi.org/10.1080/00207543.2016.1207816.

[6] D. Bogataj, D. Hudoklin, M. Bogataj, V. Dimovski, and S. Colnar, "Risk Mitigation in a Meat Supply Chain with Options of Redirection," Sustainability, vol. 12, no. 20, p. 8690, 2020. https://doi.org/10.3390/su12208690.

[7] I. Nyoman Pujawan and L. H. Geraldin, "House of risk: a model for proactive supply chain risk management," Business Process Management Journal, vol. 15, no. 6, pp. 953-967, 2009. https://doi.org/10.1108/14637150911003801.

[8] A. Rusdiansyah and M. F. Ibrahim, "Development of Risk Evaluation and Mitigation Systems for Logistics System," Jurnal Teknik Industri, vol. 21, no. 1, pp. 92-103, 2020. https://doi.org/10.22219/JTIUMM.Vol21.No1.92-103.

[9] M. S. Ab Talib and T. Ai Chin, "Halal food standard implementation: are Malaysian firms proactive or reactive?," British Food Journal, vol. 120, no. 6, pp. 1330-1343, 2018. https://doi.org/10.1108/BFJ-07-2017-0366.

[10] N. Africa, "A research framework of the halal certification role in purchase intention of Muslim consumers on the food products from Muslim majority countries in The Middle East and North Africa," International Journal of Industrial Marketing, vol. 1, no. 2, pp. 15-28, 2018.

[11] F. Lestari, Hertina, L. Ritia, I. N. Riandika, and A. Mas'ari, "Impact of Halal Labeling on Brand Image on Cosmetic Product," in 2020 IEEE International Conference on Industrial Engineering and Engineering Management (IEEM), 2020, pp. 883-887. https://doi.org/10.1109/IEEM45057.2020.9309916.

[12] I. P. I. M. Sufa'atin, "Untuk Mengidentifikasi Kemungkinan dan Dampak Risiko Proyek," ULTIMA InfoSys, vol. 8, no. 1, pp. 45-47, 2017.

[13] S. Khan, M. I. Khan, A. Haleem, and A. R. Jami, "Prioritising the risks in Halal food supply chain: an MCDM approach," Journal of Islamic Marketing, vol. aheadof-print, no. ahead-of-print, 2019. https://doi.org/10.1108/JIMA-10-2018-0206.

[14] K. Wolff, S. Larsen, and T. Øgaard, "How to define and measure risk perceptions," Annals of Tourism Research, vol. 79, p. 102759, 2019. https://doi.org/10.1016/j.annals.2019.102759.

[15] E. Ahoa, A. Kassahun, and B. Tekinerdogan, "Configuring supply chain business processes using the SCOR reference model," in International Symposium on Business Modeling and Software Design, 2018, vol. 427, pp. 338-351: Springer. https://doi.org/10.1007/978-3-319-94214-8_25. 
[16] A. Abbaspour, "Supply chain analysis and improvement by using the SCOR model and Fuzzy AHP: A Case Study," (in en), International Journal of Industrial Engineering and Management Science, vol. 6, no. 2, pp. 51-73, 2019.

[17] J. Nadaf, M. Nadaf, B. Jamadar, K. Thejaswi, and Technology, "Qualitative Risk Analysis for Construction Projects," International Research Journal of Engineering, vol. 5, no. 6, pp. 1649-1654, 2018.

[18] M. A. Kassem, M. A. Khoiry, and N. Hamzah, "Using probability impact matrix (PIM) in analyzing risk factors affecting the success of oil and gas construction projects in Yemen," International Journal of Energy Sector Management, vol. 14, pp. 527-546, 2019 2019. https://doi.org/10.1108/IJESM-03-2019-0011.

[19] M. Kassem, M. A. Khoiry, and N. Hamzah, "Using Relative Importance Index Method for Developing Risk Map in Oil and Gas Construction Projects," Jurnal Kejuruteraan, vol. 32, pp. 85-97, 08/13 2020. http://doi.org/10.17576/jkukm-202032(3)-09.

[20] Y. Rashid, A. Rashid, M. A. Warraich, S. S. Sabir, and A. Waseem, "Case study method: A step-by-step guide for business researchers," International Journal of Qualitative Methods, vol. 18, p. 1609406919862424, 2019. https://doi.org/10.1177/1609406919862424.

[21] G. Gholampour, A. R. B. Abdul Rahim, and F. Gholampour, "A Qualitative Research on Strategic Performance of Supply Chain- A Case study in Automotive Industry," IUST, vol. 29, no. 4, pp. 497-513, 2018. http://doi.org/10.22068/ijiepr.29.4.497.

[22] T. G. Abisay and N. Nurhadi, "Manajemen Risiko Pada Bandara Soekarno Hatta Berbasis ISO 31000," Jurnal Teknik Industri, vol. 14, no. 2, pp. 116-130, 2013. https://doi.org/10.22219/JTIUMM.Vol14.No2.116-130.

[23] L. A. Palinkas, S. M. Horwitz, C. A. Green, J. P. Wisdom, N. Duan, and K. Hoagwood, "Purposeful Sampling for Qualitative Data Collection and Analysis in Mixed Method Implementation Research," Administration and Policy in Mental Health and Mental Health Services Research, vol. 42, no. 5, pp. 533-544, 2015. http://doi.org/10.1007/s10488-013-0528-y.

[24] D. P. Restuputri, "Penilaian risiko gangguan musculoskeletal disorder pekerja batik dengan menggunakan metode strain index," Jurnal Teknik Industri, vol. 19, no. 1, pp. 97-106, 2018. https://doi.org/10.22219/JTIUMM.Vol19.No1.97-106.

[25] R. Ahmed, "Risk Mitigation Strategies in Innovative Projects," in Key Issues for Management of Innovative Projects: IntechOpen, 2017. http://dx.doi.org/10.5772/intechopen.69004.

[26] M. S. B. A. Abd El-Karim, O. A. Mosa El Nawawy, and A. M. Abdel-Alim, "Identification and assessment of risk factors affecting construction projects," HBRC Journal, vol. 13, no. 2, pp. 202-216, 2017. https://doi.org/10.1016/j.hbrcj.2015.05.001.

[27] G. Hariharan, P. Suresh, and S. Nagarajan, "Supply chain risk mitigation strategies and its performance of SMEs," International Journal of Pure Applied Mathematics and Computation, vol. 119, no. 15, pp. 3545-3553, 2018.

[28] J. Namdar, X. Li, R. Sawhney, and N. Pradhan, "Supply chain resilience for single and multiple sourcing in the presence of disruption risks," International Journal of Production Research, vol. 56, no. 6, pp. 2339-2360, 2018. https://doi.org/10.1080/00207543.2017.1370149.

[29] D. Nukeriana, "Implementasi Sertifikasi Halal Pada Produk Pangan Di Kota Bengkulu," Qiyas: Jurnal Hukum Islam Dan Peradilan, vol. 3, no. 2, pp. 154-165, 2018. http://dx.doi.org/10.29300/qys.v3i2.1310. 
[30] M. Neio Demirci, J. M. Soon, and C. A. Wallace, "Positioning food safety in Halal assurance," Food Control, vol. 70, pp. 257-270, 2016. https://doi.org/10.1016/j.foodcont.2016.05.059.

[31] A. N. Lau, M. H. Jamaludin, J. M. J. N. Soon, and F. Science, "Quality assurance and halal control points for the food industry," vol. 46, pp. 557-570, 2016. https://doi.org/10.1108/NFS-03-2016-0026.

[32] A. Faridah, "Identifikasi Titik Kritis Kehalalan Pangan di Rumah Makan Ampalu Raya Padang," Jurnal Kapita Selekta Geografi, vol. 2, no. 10, pp. 16-25, 2019. https://doi.org/10.24036/ksgeo.v2i10.326.

[33] M. J. Jannah, "Analisis Titik Kritis Keharaman Produk Pada Umkm Kerupuk," Jurnal Agroindustri Halal, vol. 6, no. 2, pp. 205-216, 2020. https://doi.org/10.30997/jah.v6i2.2564.

[34] Y. Atma, M. Taufik, and H. Seftiono, "Identifikasi resiko titik kritis kehalalan produk pangan: studi produk bioteknologi," Jurnal Teknologi, vol. 10, no. 1, pp. 5966, 2018. https://doi.org/10.24853/jurtek.10.1.59-66.

[35] P. S. Noerdyah, R. Astuti, and S. Sucipto, "Mitigasi risiko kesejahteraan hewan, kehalalan, dan keamanan rantai pasok industri daging ayam broiler skala menengah," Livestock Animal Research, vol. 18, no. 3, pp. 311-325, 2020. https://103.23.224.239/lar/article/view/46014.

[36] A. Ridwan, D. L. Trenggonowati, and V. Parida, "Usulan Aksi Mitigasi Risiko Rantai Pasok Halal Pada Ikm Tahu Bandung Sutra Menggunakan Metode House of Risk," Journal Industrial Servicess, vol. 5, no. 1, 2019. http://dx.doi.org/10.36055/jiss.v5i1.6512.

[37] Sufa'atin, "Untuk Mengidentifikasi Kemungkinan dan Dampak Risiko Proyek," Implementasi Probability Impact Matriks ULTIMA InfoSys, vol. 8, no. 1, pp. 45-47, 2017. 